\title{
Oct4 induces EMT through LEF1/ $\beta$-catenin dependent WNT signaling pathway in hepatocellular carcinoma
}

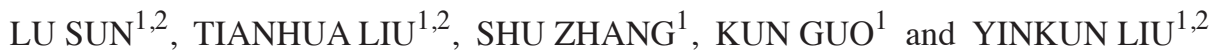 \\ ${ }^{1}$ Liver Cancer Institute, Zhongshan Hospital, Key Laboratory of Carcinogenesis and Cancer Invasion, Fudan University, \\ Ministry of Education; ${ }^{2}$ Institute of Biomedical Sciences, Fudan University, Shanghai 200032, P.R. China
}

Received August 18, 2015; Accepted December 21, 2016

DOI: $10.3892 / \mathrm{ol} .2017 .5788$

\begin{abstract}
Octamer 4 (Oct4), a member of the Pit-Oct-Unc transcription factor family required to maintain self-renewal and pluripotency of embryonic stem cells, has been previously identified to be associated with tumorigenesis and malignant transformation of numerous types of cancer including hepatocellular carcinoma (HCC). The present data shows that Oct4 enhances cancer stem cell properties and increases invasion ability in the Huh7 cell line. To increase understanding of the role of Oct4 in HCC, the present study used a functional genomics approach and analyzed the resulting transcriptional profiles to identify Oct4-dependent genes in Huh7. Affymetrix GeneChip Human genome U133 Plus 2.0 Arrays were used to determine differential gene expression profiles and then validated by quantitative polymerase chain reaction. The present study found that altered expression of 673 genes (fold-change $\geq 2$ ) affected multiple signaling pathways linked with self-renew and metastasis. Among these differentially expressed genes, the present study noticed that the key component of the WNT signaling pathway lymphoid enhancer binding factor 1 (LEF1) and Twist Family BHLH transcription factor 1 were upregulated by Oct4, whilst cadherin 2 was downregulated. Additional studies found that the nuclear $\beta$-catenin aggregation was increased in Oct 4 overexpressed HCC cell lines. These results suggest that Oct 4 regulates LEF1 to active LEF1/ $\beta$-catenin dependent WNT signaling pathway and promote epithelial-mesenchymal transition. The present findings provide novel mechanistic insight into an important role of Oct4 in HCC.
\end{abstract}

\section{Introduction}

Hepatocellular carcinoma ( $\mathrm{HCC}$ ), one of the most common and aggressive types of cancer, is the third leading cause of cancer

Correspondence to: Professor Yinkun Liu, Institute of Biomedical Sciences, Fudan University, Mingdao Building, 138 Yixueyuan Road, Shanghai 200032, P.R. China

E-mail: liu.yinkun@zs-hospital.sh.cn

Key words: hepatocellular carcinoma, octamer 4, WNT signaling pathway, epithelial-mesenchymal transition mortality globally (1). Despite the previous achievements in diagnostic and therapeutic techniques, the prognosis of HCC remains unsatisfactory. The high postoperative recurrence rate and metastasis are the key reasons for poor prognosis. Consequently, understanding the regulatory mechanisms that control tumor-initiation and metastasis is important to improve patient survival.

Octamer 4 (Oct4; also termed POU5F1) is a member of the Pit-Oct-Unc (POU)-domain transcription factor family, and acts as master transcription factor involved in maintenance and regulation of the pluripotent state (2-7). Oct4 has been found to participate in tumorigenicity and tumor progression in various cancer cells such as breast, prostate, gastric, colorectal, non-small cell lung and bladder cancer, glioma and human endometrial adenocarcinoma (8-13). Previous studies have demonstrated that the expression level of Oct4 was increased in HCC, and significantly associated with poor prognosis (14-16). Nevertheless, there remain limited studies on the role of Oct4 in HCC.

Here, the present study examined the gene expression profile of Oct4 overexpressed Huh7 cell line in comparison with a control using a whole genome approach to identify Oct4-dependent genes. The present study detected the altered expression of 673 genes (fold-change $\geq 2$ ), including CTBP2, DKK1, FZD4, FZD8, WNT2B, lymphoid enhancer binding factor 1 (LEF1), LIFR, SOCS1, SOS2, GAS1, JAG1, ACVR1C, LTBP1 and THBS1 which affect multiple signaling pathways linked with self-renewal and metastasis. Based on these findings, it is assumed that Oct 4 not only maintains stemness properties, but also performs a key role in tumor metastasis in HCC.

The cancer stem cell (CSC) theory suggests that only a small proportion of cells with stem cell-like features are responsible for tumor initiation and maintenance. There have been abundant studies that support the existence of CSCs in tumors such as leukemia and prostate, liver, brain, colon and pancreatic cancer (17-23). Previous data demonstrates that CSCs perform a critical role in tumor initiation, growth, metastasis and therapeutic resistance (24-26). Studies have suggested that CSCs have common molecules and pathways regulating self-renewal and proliferation that are similar to pluripotent embryonic stem cells. It has been demonstrated that embryonic stem cell-associated transcription regulators perform an important role in carcinogenesis and malignant 
transformation $(27,28)$. The present data also shows that Huh7 cells overexpressing Oct4 exhibit increased ability of soft agar colonization, sphere formation and invasion. From this data, the present study aims to characterize the gene regulatory network governed by Oct4 that may be used to provide insights into the molecular mechanism of carcinogenesis and metastasis in HCC.

\section{Materials and methods}

Cell culture. Huh7 cells were obtained from the American Type Culture Collection (Manassas, VA, USA). MHCC97H cells were used, which were previously established in the Liver Cancer Institute, Zhongshan Hospital, Fudan University (Shanghai, China) (29). The cell lines were cultured in Dulbecco's modified Eagle's medium (DMEM) supplemented with $10 \%$ fetal bovine serum (FBS) at $37^{\circ} \mathrm{C}$ with $5 \% \mathrm{CO}_{2}$ in air atmosphere. The DMEM and FBS were obtained from Gibco (Thermo Fisher Scientific Inc., Waltham, MA, USA).

Oct4 containing lentiviral transfection. The human Oct4 coding region was cloned from human genomic DNA and was confirmed by sequencing. The polymerase chain reaction product was then subcloned into the plasmid pLV-EF1a-IRES-GFP (Sidansai, Shanghai, China), as previously described (30). The lentivirus was produced by transfecting the packaging plasmids as well as the transfer lentiviral plasmids into HEK-293T cells with Lipofectamine 2000 (Invitrogen; Thermo Fisher Scientific Inc., Waltham, MA, USA). After $48 \mathrm{~h}$ of transfection, medium containing Oct 4 containing lentivirus was harvested and concentrated by ultracentrifugation at $30,000 \mathrm{x} g$. The concentrated lentivirus was stored at $-80^{\circ} \mathrm{C}$. Huh7 cells were infected with lentivirus at a multiplicity of infection of 10 overnight in the presence of $8 \mu \mathrm{g} / \mathrm{ml}$ of polybrene (Sigma-Aldrich; Merck Millipore, Darmstadt, Germany). Subsequent to culturing for $96 \mathrm{~h}$, the efficiency of infection was $>85 \%$ according to green fluorescent protein fluorescence as the internal control.

Sphere formation assay. Huh7 cells were plated in a 6-well plate at a density of 400 cells/ml and cultured in a serum-free DMEM medium, supplemented with epidermal growth factor (20 $\mathrm{ng} / \mathrm{ml})$, basic fibroblast growth factor $(20 \mathrm{ng} / \mathrm{ml})$ and B-27 supplement (Gibco; Thermo Fisher Scientific, Inc.). The number of spheres per well was counted directly 14 days later using a DMI 3000B Leica microscope (magnification, x200). The experiment was performed in triplicate.

Soft agar colonization. For clone formation assay, $1 \mathrm{ml}$ of $0.6 \%$ low melting point (LMP) agarose in complete medium was added to 1 well of a 6 -well plate. The gel medium was left to become solid, and then single cell suspensions of Huh7 cells were mixed with LMP agarose in a final concentration of $0.3 \%$ aliquots of $1 \mathrm{ml}$ containing 1,000 cells were plated onto a 6 -well plate. Colonies containing $>50$ cells were assessed subsequent to 14 days of incubation at $37^{\circ} \mathrm{C}$. The experiment was performed in triplicate.

Cell invasion assays. Cell invasion assays were performed in Transwell plates (Corning Life Sciences, Corning, NY, USA).
Cells in $0.5 \mathrm{ml}$ of serum-free DMEM were placed in the upper chamber which was pre-loaded with a layer of Matrigel (Sigma-Aldrich; Merck Millipore) on the upper surface, whilst the lower chamber was loaded with $0.8 \mathrm{ml}$ medium containing $10 \%$ FBS. The total number of cells that invaded to the lower chamber were stained with Giemsa and counted subsequent to incubation in $37^{\circ} \mathrm{C}$ for $48 \mathrm{~h}$. A total of 6 optimal visual fields were selected for counting.

RNA preparation. Total RNA was extracted from cultured cells using TRIzol (Invitrogen; Thermo Fisher Scientific, Inc.) according to the manufacturer's protocol. RNA quantity and quality was assessed using an Agilent 2100 BioAnalyzer (Agilent Technologies, Inc., Santa Clara, CA, USA). Only samples with an RNA integrity number average of 7-10 were used. For microarray analyses, the RNA was purified and amplified twice using the SenseAmp RNA Amplification kit (Ambion, Austin, TX, USA). The sense RNA was then labelled with the biotin-labeled antibody from the IVT Labeling kit (Affymetrix Inc., Santa Clara, CA, USA), followed by double stranded-cDNA clean up using Sample Cleanup Module (GeneChip; Affymetrix, Inc.) and fragmented RNA using fragmentation buffer (Qiagen, Inc., Valencia, CA, USA). The remaining RNA was reverse transcribed (RT) to cDNA for validation by quantitative polymerase chain reaction (qPCR). cDNA was generated in a $25 \mu \mathrm{l}$ reaction volume using $2 \mathrm{ng}$ of total RNA, Superscript III ( $0.2 \mu \mathrm{l} /$ reaction), random hexamers (9 $\mu \mathrm{g} /$ reaction), $5 \mathrm{mM}$ deoxynucleotides $(0.5 \mu \mathrm{l} /$ reaction) and 1X Superscript buffer (Invitrogen; Thermo Fisher Scientific, Inc.).

Microarray analysis. The labeled cDNA was hybridized onto an HG U133 Plus 2.0 Array (Affymetrix, Inc.) according to the standard Affymetrix protocol. The HG U133 Plus 2.0 Array contained 54,675 probes that covered the expression of over 47,000 transcripts and variants. The arrays were scanned with the GeneChip_Scanner 3000 (Affymetrix, Inc.).

$R T$ - $q P C R$. RT-qPCR was performed using 2X SYBR-Green Mix (Bio-Rad Laboratories, Inc. Hercules, CA, USA) using an iQ5 Real-Time PCR instrument (Bio-Rad Laboratories, Inc.), and each sample was run in triplicate. The human GAPDH gene was selected as endogenous control for data normalization. Primers for the reference genes and the target genes were designed using Primer Express 3.0 (Applied Biosystems; Thermo Fisher Scientific, Inc.) with melting temperatures ranging from $58-61^{\circ} \mathrm{C}$ and amplification lengths between 80-100 bp. qPCR cycling conditions were: Initial denaturation at $95^{\circ} \mathrm{C}$ for $10 \mathrm{~min} ; 40$ cycles of $95^{\circ} \mathrm{C}$ for $30 \mathrm{sec}, 60^{\circ} \mathrm{C}$ for $60 \mathrm{sec}$ and $72^{\circ} \mathrm{C}$ for $30 \mathrm{sec}$; final melt at $60-95^{\circ} \mathrm{C}$ rising by $0.5^{\circ} \mathrm{C}$ each step. Each gene expression level was calculated by a $\log$ equation $\left(2^{-\Delta \Delta \mathrm{Cq}}\right)(31)$. The used gene primer sequences are listed in Table I.

Pathway analysis. The gene functional enrichment analysis was performed using DAVID Bioinformatics Resources (32) Specifically, the Functional Annotation Clustering tool was used to enrich the overrepresented Gene Ontology (GO) terms among the differentially expressed gene (DEG) list. The HT Human Genome U133 Plus Set was used as the 
Table I. Primer sequences of genes used in the validation study.

\begin{tabular}{|c|c|}
\hline Gene & Primer sequence $\left(5^{\prime}-3^{\prime}\right)$ \\
\hline WNT2b & $\begin{array}{l}\text { F: CCTTGTCTACTTTGACAACT } \\
\text { R: GAACCTGCAGCCTTGTCCAA }\end{array}$ \\
\hline FZD4 & $\begin{array}{l}\text { F: TACCTCACAAAACCCCCATCC } \\
\text { R: GGCTGTATAAGCCAGCATCAT }\end{array}$ \\
\hline FZD8 & $\begin{array}{l}\text { F: CTACGTGGGCAACCAGAGCC } \\
\text { R: CGGATGCGGAAGAGGGACA }\end{array}$ \\
\hline LEF1 & $\begin{array}{l}\text { F: GACGAGATGATCCCCTTCAA } \\
\text { R: CGGGATGATTTCAGACTCGT }\end{array}$ \\
\hline CCND3 & $\begin{array}{l}\text { F: TTTCCTGGCCTTCATTCTG } \\
\text { R: ATCATGGATGGCGGGTAC }\end{array}$ \\
\hline СТВP2 & $\begin{array}{l}\text { F: CCACCTCATCAATGACTTTACC } \\
\text { R: AAGGCTTTCTCGTCCACC }\end{array}$ \\
\hline TGFB2 & $\begin{array}{l}\text { F: ATCCCGCCCACTTTCTAC } \\
\text { R: CCGTTGTTCAGGCACTCT }\end{array}$ \\
\hline ACVR1C & $\begin{array}{l}\text { F: ACCTGCTATTGCTCATCG } \\
\text { R: ACAGCCAACCCTAAGTCC }\end{array}$ \\
\hline LTBP1 & $\begin{array}{l}\text { F: ATTCCACATACTCCCACC } \\
\text { R: TACCCACAGTTCCACAGC }\end{array}$ \\
\hline THBS1 & $\begin{array}{l}\text { F: AGGGACGATGACTATGCTG } \\
\text { R: AGGACTGGGTGACTTGCT }\end{array}$ \\
\hline JAG1 & $\begin{array}{l}\text { F: CTACTGCGACTGTCTTCCC } \\
\text { R: ACAGATACAGCGATAACCATT }\end{array}$ \\
\hline GAS1 & $\begin{array}{l}\text { F: ACTGCGGCAAAGTCTTCAACGG } \\
\text { R: TGGGCATAGCCAGCATGTCCTC }\end{array}$ \\
\hline GAPDH & $\begin{array}{l}\text { F: TCAAGAAGGTGGTGAAGCAG } \\
\text { R: GAGGGGAGATTCAGTGTGGT }\end{array}$ \\
\hline
\end{tabular}

F, forward; R, reverse.

background for the GO analysis. The GO terms subsequent to correction for FDR at $\mathrm{P} \leq 0.05$ were selected for additional analysis. Array data were used to test whether entire groups of genes associated with specific pathways show differential expression. Pathways were taken from the Kyoto Encyclopedia of Genes and Genomes (KEGG) database (http://www.kegg.jp/).

Western blot analysis. Total cell lysates were separated by $10 \%$ SDS-PAGE and transferred to polyvinylidene difluoride membranes using the conventional method. The membrane was blocked by $5 \%$ milk at room temperature for $1 \mathrm{~h}$. The blotted membrane was then incubated with the antibodies for Oct4 (dilution, 1:1,000; catalog no., 2907; Epitomics, Burlingame, CA, USA), LEF1 (dilution, 1:1,000; catalog no., 2230; Cell signaling Technology, Inc., Danvers, MA, USA), E-cadherin (dilution, 1:1,000; catalog no., 610181; BD Pharmingen, San Diego, CA, USA), N-cadherin (dilution, 1:1,000; catalog no., 610921; BD Pharmingen) and GAPDH (dilution, 1:10,000; catalog no., KC-5G4; KangChen, Shanghai, China) in $5 \%$ milk. Subsequent to being washed 3 times in $0.1 \%$ TBS Tween-20, the membrane was additionally incubated with horseradish peroxidase-conjugated secondary antibody (dilution, 1:10,000; catalog no., 123-001-021; Jackson ImmunoResearch, West Grove, PA, USA) at room temperature for $1 \mathrm{~h}$, and then washed again with 0.1\% TBS Tween-20 3 times. Enhanced chemiluminescence prime western blotting detection reagents (GE Healthcare, Little Chalfont, UK) and ChemiDoc XRS ${ }^{+}$ system (Bio-Rad Laboratories, Inc.) were used to visualize the bands on the membrane.

Immunofluorescence staining. For immunofluorescence staining, the treated cells seeded on glass slides were fixed with $4 \%$ paraformaldehyde (Sigma-Aldrich; Merck Millipore) for 15 min and permeabilized with $0.1 \%$ Triton X-100 for $15 \mathrm{~min}$ at room temperature. Subsequently, cells were washed with PBS and blocked with $2 \%$ bovine serum albumin for $1 \mathrm{~h}$ at room temperature. Cells were incubated with $\beta$-catenin antibody (dilution, 1:200; catalog no., Ab32572; Abcam, Cambridge, UK) and diluted in PBS at $4{ }^{\circ} \mathrm{C}$ overnight. A negative control (primary antibody omitted) was processed in every experiment. The next day, cells were washed with PBS and incubated with working solution of Alexa Fluor 488-conjugated secondary antibody (dilution, 1:100; catalog no., 4408; Cell Signaling Technology, Inc., Danvers, MA, USA) at room temperature for $1 \mathrm{~h}$. Subsequent to rinsing in PBS, the slides were imaged immediately with a DM2500 fluorescence microscope (Leica Microsystems $\mathrm{GmbH}$, Wetzlar, Germany).

Statistical analysis. Student's t-test was used to compare two groups of parametric variants. The data were analyzed using SPSS 13.0 (SPSS Inc., Chicago, IL, USA). GraphPad Prism 5 (GraphPad Software, Inc., La Jolla, CA, USA) was used to draw the graphs. The data are expressed as the mean \pm standard error of the mean from at least 3 repeats. $\mathrm{P}<0.05$ was considered to indicate a statistically significant difference.

\section{Results}

Overexpressed Oct4 enhanced CSC properties and invasion ability of Huh7 cells. Investigations into the biological effect of Oct 4 on HCC cells, sphere formation, soft agar colonization and invasion were performed using Oct4 overexpressed Huh7 cells. It was found that Oct4 overexpressed Huh7 cells exhibited increased sphere formation, increased clone numbers in the soft agar colonization and increased invasion in the invasion assay (Fig. 1). This evidence indicated that Oct4 may drive HCC cells toward a state closer to CSC with higher invasion ability.

The expression of multiple signaling pathway genes varied following Oct4 overexpression. The microarray data revealed 673 DEGs with a fold-change $>2$ between the Oct4 overexpressed Huh7 and the control (Fig. 2A). Among them, 371 genes were upregulated and 302 genes were downregulated (data not shown). Using the functional enrichment analysis of these DEGs, the present study found that a series of biological pathways components were differentially expressed (Fig. 2B).

The majority of differentially expressed WNT signaling genes were found to be upregulated, including WNT2B $(\mathrm{fc}=2.0405), \mathrm{dkk} 1 \quad(\mathrm{fc}=3.0301)$, FZD4 $(\mathrm{fc}=2.9077), \mathrm{FZD} 8$ 

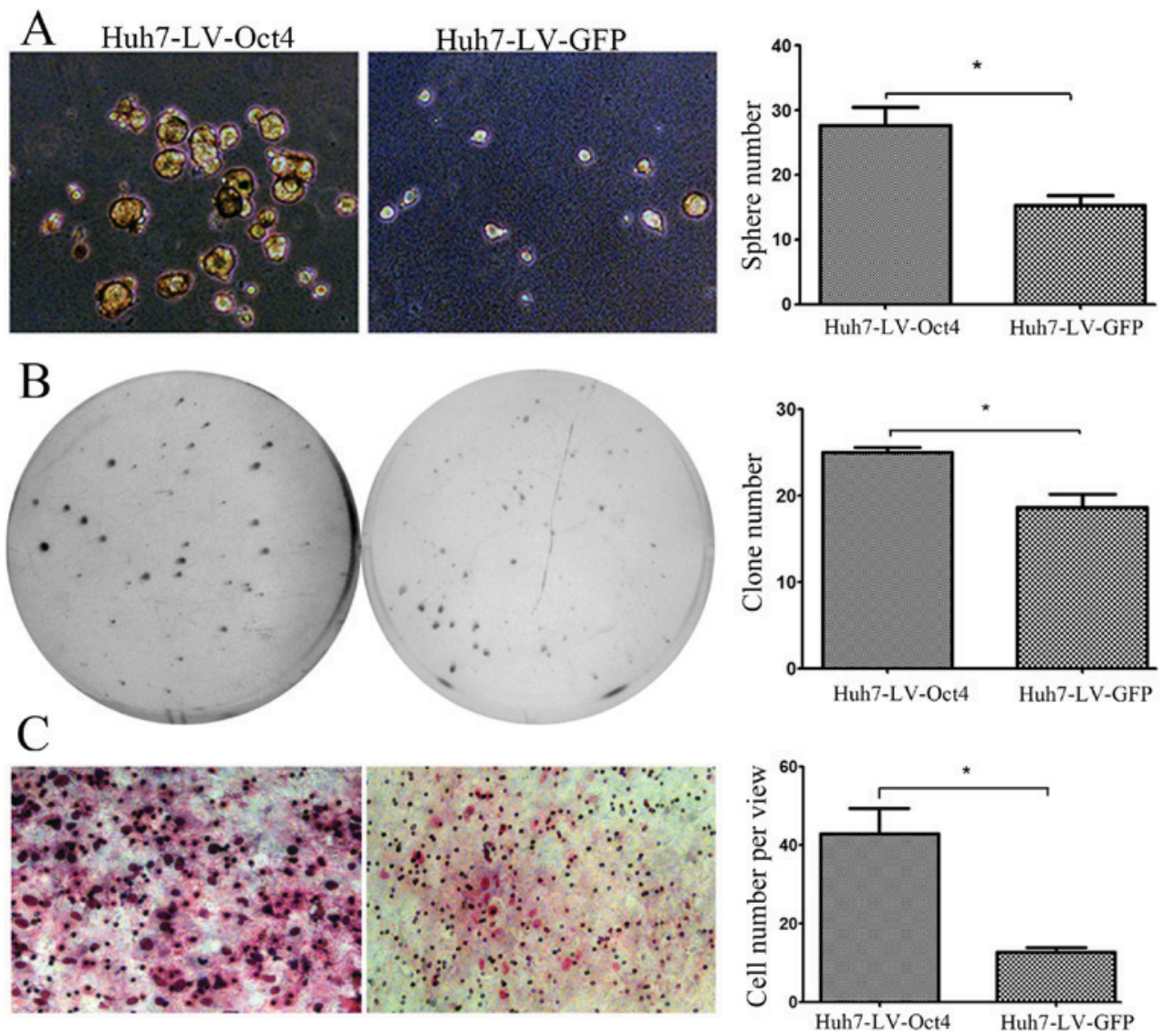

Figure 1. Oct4 expression enhances CSC property and invasion ability of HCC cell. (A) Oct4 enhances the abilities of sphere formation. (B) Oct4 enhances the abilities of soft agar colonization. (C) Oct4 enhances the abilities of Matrigel invasion. Graphs show the mean \pm standard error of the mean from at least 3 experiments compared with mock cells. ${ }^{*} \mathrm{P}<0.05$ was considered to indicate a statistically significant difference. Oct4, octamer 4; CSC, cancer stem cell; HCC, hepatocellular carcinoma; GFP, green fluorescent protein.
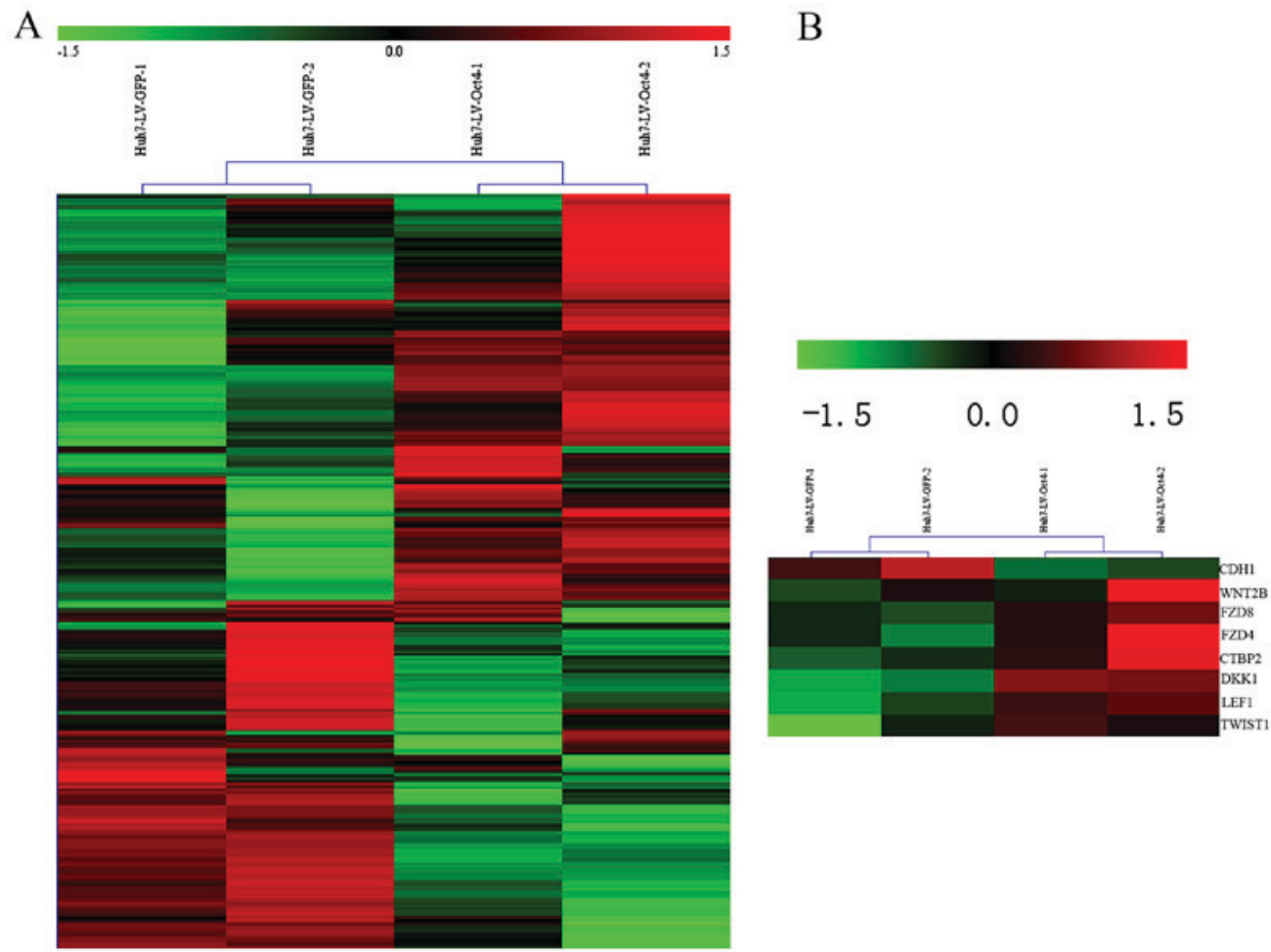

Figure 2. Heat map of differential expression genes. (A) Heat map visualization of 673 significantly regulated probe sets. The columns represent samples, whilst rows represent genes. Color key indicates gene expression value: Green, lowest and red, highest. (B) A series of pathways components were differentially expressed. 
Table II. Distribution of differentially expressed genes in multiple signaling pathways by KEGG analysis.

\begin{tabular}{|c|c|c|c|c|}
\hline Pathway ID & Pathway name & Category & DEGs & P-value \\
\hline hsa04010 & $\begin{array}{l}\text { Mitogen activated protein } \\
\text { kinase signaling pathway }\end{array}$ & Signal transduction & $\begin{array}{l}\text { IL1R2, MEF2D, TGFB2, } \\
\text { RPS6KA5, IL1R1, PLA2G12B, } \\
\text { IL1RAP, ETS1, DOCK1, DUSP6, } \\
\text { SOS2, KRAS, RPS6KA5, } \\
\text { PLA2G12B, RAP1A }\end{array}$ & \\
\hline hsa04350 & $\begin{array}{l}\text { Transforming growth } \\
\text { factor- } \beta \text { signaling pathway }\end{array}$ & Signal transduction & $\begin{array}{l}\text { SOS2, TGFB2, KRAS, HNF4A, } \\
\text { ACVR1C, INHBB }\end{array}$ & 0.002 \\
\hline hsa04310 & Wnt signaling pathway & Signal transduction & $\begin{array}{l}\text { SOX4, WNT2B, FZD8, CDH1, } \\
\text { FZD4, SOX6, TGFB2, TLE3, TLE4, } \\
\text { LEF1, SOX9, DKK1, ACVR1C, } \\
\text { POU5F1, SOX5 }\end{array}$ & 0.0079 \\
\hline hsa04630 & Jak-STAT signaling pathway & Signal transduction & SOCS1, SOS2, KRAS & 0.009 \\
\hline hsa04330 & Notch signaling pathway & Signal transduction & JAG1, HEY1 & 0.1551 \\
\hline hsa04340 & Hedgehog signaling pathway & Signal transduction & GAS 1 & 0.2011 \\
\hline hsa04060 & $\begin{array}{l}\text { Cytokine-cytokine receptor } \\
\text { interaction }\end{array}$ & $\begin{array}{l}\text { Signaling molecules } \\
\text { and interaction }\end{array}$ & $\begin{array}{l}\text { CCL2, CXCL, SOCS1, IRS2, } \\
\text { KRAS }\end{array}$ & \\
\hline hsa04530 & Tight junction & Cell communication & $\begin{array}{l}\text { CLDN11, MYL6, JAM3, CLDN1, } \\
\text { PVRL3, CEBPA, TGFB2, CLDN14 }\end{array}$ & 0.0157 \\
\hline hsa05200 & Pathways in cancer & Cancers & $\begin{array}{l}\text { AKR1C1/AKR1C2, ALB, ANXA1, } \\
\text { CD109, CD82, CDH1, CYP2C18, } \\
\text { CYP-2C9, DKK1, E2F1, FGA, } \\
\text { FGF2, FGL1, FOXQ1, GABRE, } \\
\text { GJB1, GPC3, HPSE, HPX, IL8, } \\
\text { IQGAP2, KNG1, KRAS, LEF1, } \\
\text { LIF, MAG }\end{array}$ & \\
\hline hsa04062 & Chemokine signaling pathway & Immune system & CCL2, CXCL12, GNAI1, KRAS & \\
\hline hsa04610 & $\begin{array}{l}\text { Complement and coagulation } \\
\text { cascades }\end{array}$ & Immune system & $\begin{array}{l}\text { SERPING1, CD55, C3, CFI, C8B, C5, } \\
\text { C8A, C8G }\end{array}$ & \\
\hline hsa04670 & $\begin{array}{l}\text { Leukocyte transendothelial } \\
\text { migration }\end{array}$ & Immune system & $\begin{array}{l}\text { CLDN11, MYL6, JAM3, CLDN1, } \\
\text { MMP16, VAV3, CXCL12, GNAI1, } \\
\text { CLDN14, RAP1A, TIMP2 }\end{array}$ & 0.0005 \\
\hline hsa05322 & Systemic lupus erythematosus & Immune disorders & $\begin{array}{l}\text { KNG1, CREM, SOS2, C8B, KRAS, } \\
\text { C5, C8A, C8G }\end{array}$ & 0.0189 \\
\hline hsa03320 & PPAR signaling pathway & Endocrine system & $\begin{array}{l}\text { IL1R2, NR2F1, NR0B2, SOS2, } \\
\text { KRAS, IL1R1, IL1RAP }\end{array}$ & \\
\hline hsa00010 & Glycolysis/gluconeogenesis & $\begin{array}{l}\text { Carbohydrate } \\
\text { Metabolism }\end{array}$ & ALDOB & 0.0027 \\
\hline hsa00330 & $\begin{array}{l}\text { Arginine and proline } \\
\text { metabolism }\end{array}$ & $\begin{array}{l}\text { Amino acid } \\
\text { Metabolism }\end{array}$ & ASS1, ARG2, ARG1 & 0.0016 \\
\hline
\end{tabular}

$(\mathrm{fc}=2.0289), \mathrm{LEF} 1(\mathrm{fc}=2.3173), \mathrm{CCND} 3(\mathrm{fc}=2.2184)$ and CTBP2 (fc=3.4984).

Transforming growth factor- $\beta$ (TGF- $\beta$ ) 2 , as a member of the TGF- $\beta$ superfamily, was downregulated ( $\mathrm{fc}=0.4788)$. ACVR1C also teremd activin A receptor was upregulated ( $\mathrm{fc}=2.191)$. As a type I receptor for the TGF- $\beta$ family, ACVR1C can transduce signals by forming a complex with Nodal and ACVR2B. Oct4 overexpression also increases expression of other TGF- $\beta$ signaling regulator such as LTBP1 $(\mathrm{fc}=2.1327)$ and THBS1 $(\mathrm{fc}=2.3411)$.

Examination of NOTCH pathway components revealed upregulation of JAG1 ( $\mathrm{fc}=2.1993)$. Analysis of hedgehog signaling components showed upregulated level of GAS1 (fc=8.121).
It is worth noting that the CDH1 (encoded E-cadherin) was downregulated $(\mathrm{fc}=0.395)$ and functional loss of $\mathrm{E}$-cadherin is regarded as one of the hallmark of epithelial-mesenchymal transition (EMT). In addition the EMT marker, transcription factor Twist Family BHLH transcription factor 1 (Twist1) was upregulated $(\mathrm{fc}=2.031)$.

The pathways that were significantly differentially expressed are listed in Table II, including the mitogen activated protein kinase, WNT, TGF- $\beta$, notch and hedgehog signal pathway.

Validation of the microarray gene expression profile was then performed by RT-qPCR analysis. The present study tested the expression levels of TGF- $\beta$, WNT, Notch and Hedgehog 


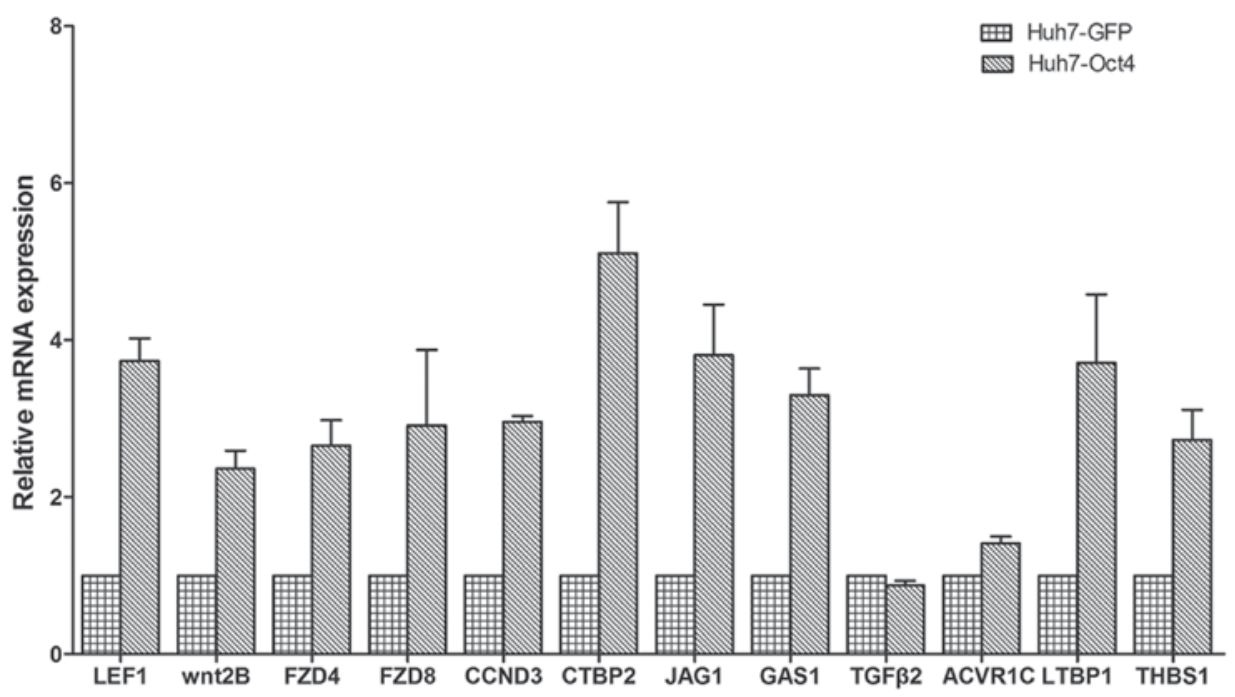

Figure 3. Validation of the gene expression profile of microarrays by reverse transcription-quantitative polymerase chain reaction. The results indicate that the DEG expression profile were mostly consistent with the microarray data analysis. The human GAPDH gene was selected as assay endogenous control for data normalization. Each gene expression level was calculated by a log equation $\left(2^{-\triangle \Delta \mathrm{Cq}}\right)$. LEF1, wnt2B, FZD4, FZD8, CCND3, CTBP2, JAG1, GAS1, TGF 2 , ACVR1C, LTBP1 and THBS1 were upregulated following Oct4 overexpression. Graphs show mean \pm standard error of the mean performed in triplicate. Oct4, octamer 4; GFP, green fluorescent protein; LEF1, lymphoid enhancer binding factor 1.

A

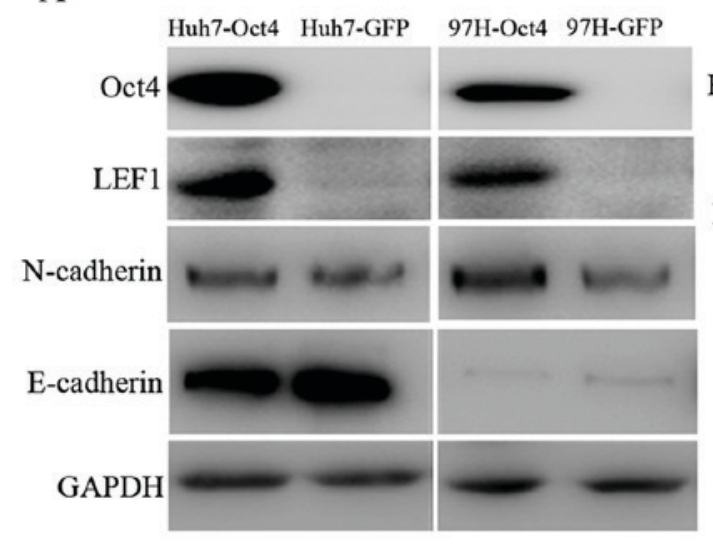

B

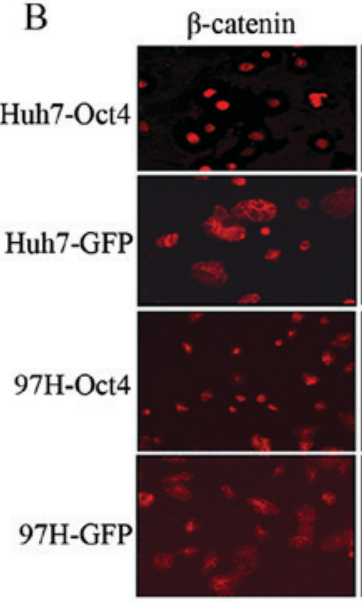

DAPI

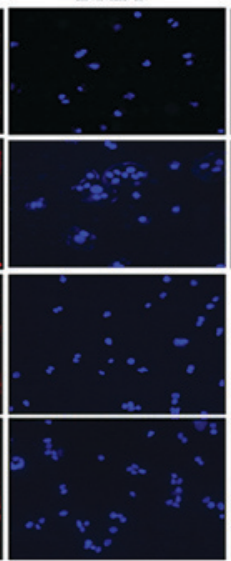
Merge

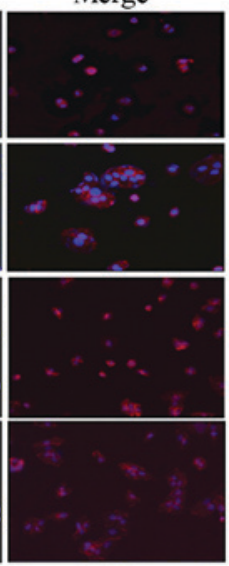

Figure 4. Oct4 activates LEF1/ $\beta$-catenin dependent WNT signaling pathway and induces EMT. (A) Western blot analysis of EMT marker and LEF1. LEF1 and $\mathrm{N}$-cadherin was upregulated in Oct 4 overexpression cell lines, and E-cadherin expression was inhibited. (B) Immunofluorescence analysis of $\beta$-catenin shows that nuclear accumulation was promoted in Oct4 overexpression cell lines. Oct4, octamer 4; LEF1, lymphoid enhancer binding factor 1; EMT, epithelial-mesenchymal transition; GFP, green fluorescent protein.

signaling pathway genes (Fig. 3). The results of the RT-qPCR analysis for the DEGs were mostly consistent with the results from the microarray data analysis.

Oct4 activated LEF $1 / \beta$-catenin dependent WNT signaling pathway and induced EMT. The array data showed that LEF1, which is an important component of WNT signaling pathway, was upregulated; additional western blot analysis experiments proved that LEF1 was a target gene of Oct4 (Fig. 4A). Considering LEF1 is an interaction partner of $\beta$-catenin and differential expression of $\beta$-catenin was not observed, additional investigation is required to confirm the localization of $\beta$-catenin. Immunofluorescence staining shows that Oct 4 promotes the accumulation of nuclear $\beta$-catenin, which is the hallmark of WNT signaling activation (Fig. 4B). The expression of classical markers of EMT including E-cadherin and $\mathrm{N}$-cadherin were assessed by western blot analysis. In Huh7 and MHCC97H, inhibition of E-cadherin and elevation of $\mathrm{N}$-cadherin were found when Oct4 was overexpressed (Fig. 4A).

\section{Discussion}

CSCs are a subpopulation of cancer cells that possess characteristics of normal stem cells in solid tumors. Self-renewal activity and pluripotency are the most notable hallmarks of CSCs. Studies have suggested that the molecular signatures of CSCs are similar to pluripotent ESCs $(27,28)$. The POU domain transcription factor Oct4 is a gatekeeper of self-renewal and critical regulator of a transcription factor network in human ESCs $(33,34)$. Downregulation of Oct4 expression or epigenetic silencing of the promoter blocks self-renewal and 
pluripotency and triggers differentiation programs, which indicates that Oct4 is essential to establish and maintain pluripotency in ESCs (35). It has also been confirmed that Oct4 expression is essential for CSC-like properties in various types of cancer $(36,37)$. The present study determined that HCC cells with Oct 4 overexpression acquired a stronger ability in sphere formation, soft agar colonization and invasion compared with mock cells. This finding is in accordance with phenomena previously observed (38), indicating that CSC-like properties and metastasis were enhanced by Oct 4 overexpression.

Normal stem cell self-renewal and differentiation is tightly controlled by multiple developmental pathways, such as WNT, Notch and Hedgehog. These signaling pathways also contribute to controlling cancer progression $(39,40)$. From the present array data, multiple signaling pathways including WNT, TGF- $\beta$, Notch and Hedgehog were all involved. Among these, the effect on WNT pathways is the most evident. The majority of differentially expressed WNT signaling genes were found to be upregulated, including WNT2B, FZD4, FZD8, LEF1, dkk1, CCND3 and CTBP2. The canonical WNT pathway is initiated by WNT protein binding to the Frizzled receptor on the cell surface. Signals downstream of these receptors lead to inactivation of GSK-3 $\beta$, resulting in the nuclear accumulation of $\beta$-catenin, which activates the transcription of target genes in collaboration with the T-cell factor/lymphoid enhancer factor1 (Tcf/Lef1) family of transcription factor. By further western blot analysis, it was determined that Lef1 was upregulated by Oct4 in HCC cell lines. The expression of $\beta$-catenin was not effected but the $\beta$-catenin nuclear accumulation was observed in Oct4 overexpressed HCC cells. Since $\beta$-catenin does not contain a nuclear localization signal and evidence has emerged showing that $\beta$-catenin nuclear localization is regulated via interaction partners of $\beta$-catenin, the present study speculated that Oct 4 increases the $\beta$-catenin nuclear accumulation through LEF1 to active the WNT signaling pathway (41).

From the microarray data, the present study also noticed that the Twist1 transcription factor was upregulated and the epithelial marker E-cadherin encoding by chd1 gene was downregulated. These findings suggest that Oct4 overexpression can induce epithelial-mesenchymal transition (EMT) process in HCC. EMT is a critical process involved in cancer progression and metastasis and mounting data has demonstrated that the acquisition of invasive characteristics of tumor is associated with the process (42-44). In addition, emerging evidence also suggests a role for EMT in generating CSC-like features (45-47). Therefore, it was assumed that Oct4 may enhance the CSC-like properties and metastasis by inducing the EMT process.

Notably, the canonical WNT pathway performs a key role in EMT initiation (48). Translocation of $\beta$-catenin from the adhesion junction to the nucleus lead to the loss of E-cadherin and EMT processes. The present findings therefore suggest that Oct4 enhance CSC-like property of HCC cells in vitro. Overexpressed Oct 4 activates the LEF1/ $\beta$-catenin dependent WNT signaling pathway to promote EMT. Oct4 promote HCC cell CSC-like property may be through activation of EMT. The present results presented novel mechanistic sight into an important role of Oct4 in HCC and suggest a potential application of Oct4 in HCC prognosis and treatment.

\section{Acknowledgements}

The present study was supported by the Major State Basic Research Development Program of China (grant no. 2013CB910501) and the Shanghai Natural Science Foundation (grant no. 12ZR1405900).

\section{References}

1. Parkin DM, Bray F, Ferlay J and Pisani P: Global cancer statistics, 2002. CA Cancer J Clin 55: 74-108, 2005.

2. Babaie Y, Herwig R, Greber B, Brink TC, Wruck W, Groth D, Lehrach H, Burdon T and Adjaye J: Analysis of oct4-dependent transcriptional networks regulating self-renewal and pluripotency in human embryonic stem cells. Stem Cells 25: 500-510, 2007.

3. Guo Y, Mantel C, Hromas RA and Broxmeyer HE: Oct-4 is critical for survival/antiapoptosis of murine embryonic stem cells subjected to stress: Effects associated with Stat3/survivin. Stem Cells 26: 30-34, 2008.

4. Okita K, Ichisaka T and Yamanaka S: Generation of germline-competent induced pluripotent stem cells. Nature 448: 313-317, 2007.

5. Boyer LA, Lee TI, Cole MF, Johnstone SE, Levine SS, Zucker JP, Guenther MG, Kumar RM, Murray HL, Jenner RG, et al: Core transcriptional regulatory circuitry in human embryonic stem cells. Cell1 122: 947-956, 2005.

6. Yuan P, Han J, Guo G, Orlov YL, Huss M, Loh YH, Yaw LP, Robson P, Lim B and Ng HH: Eset partners with Oct4 to restrict extraembryonic trophoblast lineage potential in embryonic stem cells. Genes Dev 23: 2507-2520, 2009.

7. Stefanovic S, Abboud N, Désilets S, Nury D, Cowan C and Puceat M: Interplay of Oct4 with Sox2 and Sox17: A molecular switch from stem cell pluripotency to specifying a cardiac fate. J Cell Biol 186: 665-673, 2009.

8. Ezeh UI, Turek PJ, Reijo RA and Clark AT: Human embryonic stem cell genes OCT4, NANOG, STELLAR, and GDF3 are expressed in both seminoma and breast carcinoma. Cancer 104: 2255-2265, 2005.

9. Gu G, Yuan J, Wills M and Kasper S: Prostate cancer cells with stem cell characteristics reconstitute the original human tumor in vivo. Cancer Res 67: 4807-4815, 2007.

10. Chen YC, Hsu HS, Chen YW, Tsai TH, How CK, Wang CY, Hung SC, Chang YL, Tsai ML, Lee YY, et al: Oct-4 expression maintained cancer stem-like properties in lung cancer-derived cd133-positive cells. PLoS One 3: e2637, 2008.

11. Atlasi Y, Mowla SJ, Ziaee SA and Bahrami AR: OCT-4, an embryonic stem cell marker, is highly expressed in bladder cancer. Int J Cancer 120: 1598-1602, 2007.

12. Chang CC: Recent translational research: Stem cells as the roots of breast cancer. Breast Cancer Res 8: 103, 2006.

13. Du Z, Jia D, Liu S, Wang F, Li G, Zhang Y, Cao X, Ling EA and Hao A: Oct 4 is expressed in human gliomas and promotes colony formation in glioma cells. Glia 57: 724-733, 2009.

14. Dong Z, Zeng Q, Luo H, Zou J, Cao C, Liang J, Wu D and Liu L: Increased expression of OCT4 is associated with low differentiation and tumor recurrence in human hepatocellular carcinoma. Pathol Res Pract 208: 527-533, 2012.

15. Yin X, Li YW, Zhang BH, Ren ZG, Qiu SJ, Yi Y and Fan J: Coexpression of stemness factors Oct4 and Nanog predict liver resection. Ann Surg Oncol 19: 2877-2887, 2012.

16. Huang P, Qiu J, Li B, Hong J, Lu C, Wang L, Wang J, Hu Y, Jia W and Yuan Y: Role of Sox 2 and Oct4 in predicting survival of hepatocellular carcinoma patients after hepatectomy. Clin Biochem 44: 582-589, 2011.

17. Collins AT, Berry PA, Hyde C, Stower MJ and Maitland NJ: Prospective identification of tumorigenic prostate cancer stem cells. Cancer Res 65: 10946-10951, 2005.

18. Wang JC and Dick JE: Cancer stem cells: Lessons from leukemia. Trends Cell Biol 15: 494-501, 2005.

19. Yang ZF, Ngai P, Ho DW, Yu WC, Ng MN, Lau CK, Li ML, Tam KH, Lam CT, Poon RT and Fan ST: Identification of local and circulating cancer stem cells in human liver cancer. Hepatology 47: 919-928, 2008.

20. Singh SK, Clarke ID, Terasaki M, Bonn VE, Hawkins C, Squire J and Dirks PB: Identification of a cancer stem cell in human brain tumors. Cancer Res 63: 5821-5828, 2003. 
21. O'Brien CA, Pollett A, Gallinger S and Dick JE: A human colon cancer cell capable of initiating tumour growth in immunodeficient mice. Nature 445: 106-110, 2007.

22. Li C, Heidt DG, Dalerba P, Burant CF, Zhang L, Adsay V, Wicha M, Clarke MF and Simenoe DM: Identification of pancreatic cancer stem cells. Cancer Res 67: 1030-1037, 2007.

23. Visvader JE and Lindeman GJ: Cancer stem cells in solid tumours: Accumulating evidence and unresolved questions. Nat Rev Cancer 8: 755-768, 2008

24. Mani SA, Guo W, Liao MJ, Eaton EN, Ayyanan A, Zhou AY, Brooks M, Reinhard F, Zhang CC, Shipitsin M, et al: The epithelial-mesenchymal transition generates cells with properties of stem cells. Cell 133: 704-715, 2008.

25. Gupta PB, Chaffer CL and Weinberg RA: Cancer stem cells: Mirage or reality? Nat Med 15: 1010-1012, 2009

26. Bao S, Wu Q, McLendon RE, Hao Y, Shi Q, Hjelmeland AB, Dewhirst MW, Bigner DD and Rich JN: Glioma stem cells promote radioresistance by preferential activation of the DNA damage response. Nature 444: 756-760, 2006.

27. Ben-Porath I, Thomson MW, Carey VJ, Ge R, Bell GW, Regev A and Weinberg RA: An embryonic stem cell-like gene expression signature in poorly differentiated aggressive human tumors. Nat Genet 40: 499-507, 2008.

28. Wong DJ, Liu H, Ridky TW, Cassarino D, Segal E and Chang HY Module map of stem cell genes guides creation of epithelial cancer stem cells. Cell Stem Cell 2: 333-344, 2008.

29. Li Y, Tian B, Yang J, Zhao L, Wu X, Ye SL, Liu YK and Tang ZY: Stepwise metastatic human hepatocellular carcinoma cell model system with multiple metastatic potentials established through consecutive in vivo selection and studies on metastatic characteristics. J Cancer Res Clin Oncol 130: 460-468, 2004.

30. Liao J, Cui C, Chen S, Ren J, Chen J, Gao Y, Li H, Jia N, Cheng L, Xiao $\mathrm{H}$ and Xiao L: Generation of induced pluripotent stem cell lines from adult rat cells. Cell Stem Cell 4: 11-15, 2009.

31. Livak KJ and Schmittgen TD: Analysis of relative gene expression data using real-time quantitative PCR and the 2(-Delta Delta C(T) Method. Methods Dec 25: 402-408, 2001.

32. Huang da W, Sherman BT, Zheng X, Yang J, Imamichi T, Stephens R and Lempicki RA: Extracting biological meaning from large gene lists with DAVID. Curr Protoc Bioinformatics Chapter 13: Unit 13.11, 2009.

33. Kim J, Chu J, Shen X, Wang J and Orkin SH: An extended transcriptional network for pluripotency of embryonic stem cells. Cell 132: 1049-1061, 2008

34. Pardo M, Lang B, Yu L, Prosser H, Bradley A, Babu MM and Choudhary J: An expanded Oct4 interaction network: Implications for stem cell biology, development, and disease. Cell Stem Cell 6: 382-95, 2010.
35. Nichols J,Zevnik B, Anastassiadis K, Niwa H, Klewe-Nebenius D, Chambers I, Schöler H and Smith A: Formation of pluripotent stem cells in the mammalian embryo depends on the POU transcription factor Oct4. Cell 95: 379-391, 1998

36. Chiou SH, Wang ML, Chou YT, Chen CJ, Hong CF, Hsieh WJ, Chang HT, Chen YS, Lin TW, Hsu HS and Wu CW: Coexpression of Oct4 and Nanog enhances malignancy in lung adenocarcinoma by inducing cancer stem cell-like properties and epithelial-mesenchymal transdifferentiation. Cancer Res 70: 10433-10444, 2010.

37. Wang XQ, Ongkeko WM, Chen L, Yang ZF, Lu P, Chen KK, Lopez JP, Poon RT and Fan ST: Octamer 4 (Oct4) mediates chemotherapeutic drug resistance in liver cancer cells through a potential Oct4-AKT-ATP-binding cassette G2 pathway. Hepatology 52: 528-539, 2010.

38. Jia Q, Zhang X, Deng T and Gao J: Positive correlation of Oct4 and ABCG2 to chemotherapeutic resistance in CD90(+)CD(133) liver cancer stem cells. Cell Reprogram 15: 143-150, 2013.

39. Reya $\mathrm{T}$ and Clevers $\mathrm{H}$ : Wnt signalling in stem cells and cancer. Nature 434: 843-850, 2005.

40. DeSano JT and Xu L: MicroRNA regulation of cancer stem cells and therapeutic implications. AAPS J 11: 682-692, 2009.

41. Krieghoff E, Behrens J and Mayr B: Nucleo-cytoplasmic distribution of beta-catenin is regulated by retention. J Cell Sci 119: 1453-1463, 2006.

42. Lee JM, Dedhar S, Kalluri R and Thompson EW: The epithelial-mesenchymal transition: New insights in signaling, development, and disease. J Cell Biol 172: 973-981, 2006.

43. Hugo H, Ackland ML, Blick T, Lawrence MG, Clements JA, Williams ED and Thompson EW: Epithelial-mesenchymal and mesenchymal-epithelial transitions in carcinoma progression. J Cell Physiol 213: 374-383, 2007.

44. Garber K: Epithelial-to-mesenchymal transition is important to metastasis, but questions remain. J Natl Cancer Inst 100: 232-239, 2008

45. Mani SA, Guo W, Liao MJ, Eaton EN, Ayyanan A, Zhou AY, Brooks M, Reinhard F, Zhang CC, Shipitsin M, et al: The epithelialmesenchymal transition generates cells with properties of stem cells. Cell1 33: 704-715, 2008.

46. Morel AP, Lièvre M, Thomas C, Hinkal G, Ansieau S and Puisieux A: Generation of breast cancer stem cells through epithelial-mesenchymal transition. PLoS One 3: e2888, 2008.

47. Gupta PB, Onder TT, Jiang G, Tao K, Kuperwasser C, Weinberg RA and Lander ES: Identification of selective inhibitors of cancer stem cells by high-throughput screening. Cell 138: 645-659, 2009

48. Clevers $\mathrm{H}$ : Wnt/beta-catenin signaling in development and disease. Cell 127: 469-480, 2006. 